\title{
表面粗さ見本について
}

大越諄* 篠崎襄*

\section{Manufacturing of Mother Plates of Surface Roughness Scale}

\section{Makoto OGOSHI and Yuzuru SHINOZAKI}

$t$ is natural that the roughness of machined surface has much to with capacity, durability, appearance etc. of machinery. With the progress of machining technique, the standardization of surface roughness has become necessary, which many countries in the world have already established.

But it is so troublesome and tedious to measure the surface roughness with surface-roughnesstester, that the so called surface-roughness-scale with which we can find out the roughness of the surface macroscopically or by touching has more and more been called for.

Complying with the requirement, the authers manufactured roughness mother plates of various kinds of machining, and they also studied how far the limits of the roughness of every machining are.

\section{I. 緒言}

金属をはじめ種々の材料汶対する加工技術が進歩する そつれて，加工表面の粗さを規定する必要を生じ日本で も JIS B0601で表面もらさを規定している。併し唯規定 してもこれをいろいろ測定するのは仲々大変なので, 現 場作業者から, 表面女らさの各種見本を作つて, 視覚打 よび触感によつて比較判定することが要望されて来た。

第1表 粗さ見本作製計画表

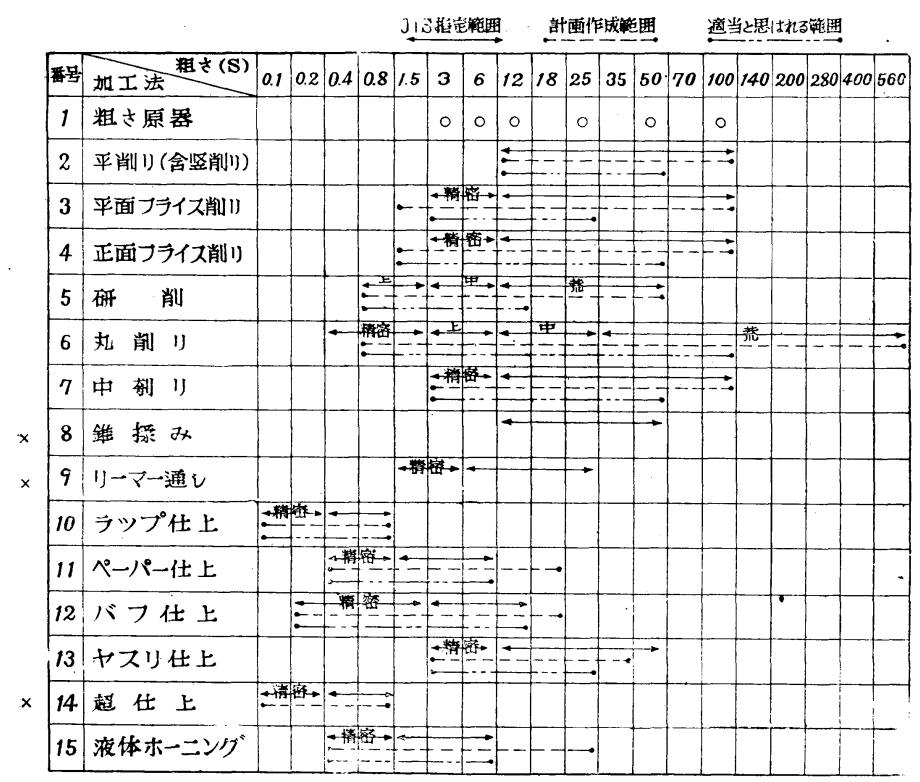

* 科学研究所
科研大越研究䇪に拀い,てねこの要望に応じて各種の表面 むらさ見本の原型を製作した。

表面粗さ規格（JIS B0601）飞は各種加工沠による粗 さの範用を示した表が記載されているが，その中から大 越研究絰に招いては第1 表に示した粗さ見本の製作を計 画した。粗さを日本では最大高さ（Hmax）で表わして いるが，国際粗さ規格案(i)るても今後は最大高さと， 平均粗さ (Have) とによる二本立ての機運が見られるの で,それ机るッチできるような原型の 製作に留意した。即ち多物で切削する加 工法の場合及物の尖端を正確な角度に研 削し，切削表面のプロフイルが周期の正 しい三角形の波になるょうとした。（第 1 図参照)
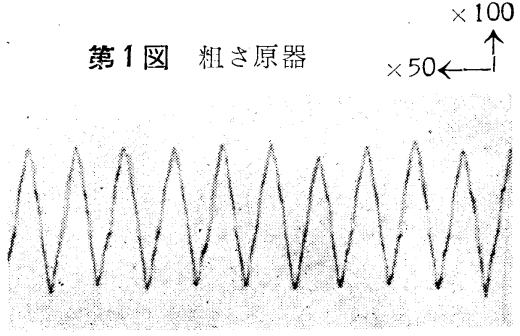

かくすれば Hmax 汸勿論 Have も直 ぐ測定出来自乘平均平方根粗さ (Hrms) も割合に簡單に計算出来るからである。 現在まで雓揉み、リーマ通し，超仕上 を除いて完成したので，各種加工法によ り粗さ見本の原型を製作するに当つて気 


\section{II. 粗さ 原 器}

粗さ原㟧と云弓のは武面安らさ娭査機の倍率の較正に

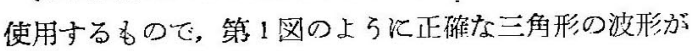
画かれるものである。

パイトの多先の触を約 $158^{\circ}$ と寸ると喵凸の高さ（则 ち粗さ）と凹円のピッチとの比が、：10になるのて，例 えば田凸の高さが $3 \mu$ の原器を作るには，0.03mm の ピッチでバイトを送ることになる。幅 $20 \mathrm{~mm}$ の原型を 作るルは約 700 回バイトを律復させるるばならず，また機

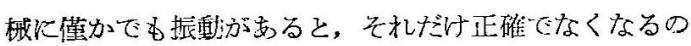

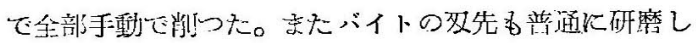
たのては䂠精の粗さがそのまま原型の粗され出て来るの で＄320のダイヤモンドホキールでラッブ什上後更に 200 倍の鼰微鏡で先を確め乍ら， \$900のダイヤモン ドスティックでラップ仕上した。厚型になる材䆩もまた 重要で steel 系統だと抵抗子大きく構成多先の影響子㐫

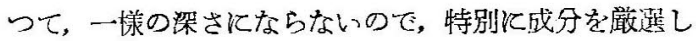
た玦削黄墑を用いた。

\section{III．平削り（㹂削りを含む）}

JIS てはこの加工法の籍囲が 12-S〜100-S となつてい

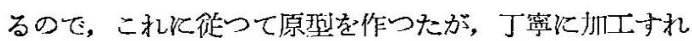
ば6-S は可能です， また仕上面の実用性名ら考之て 70-S，100-S は不必要ではないかと思われる。第2図は 平削り粗さ見本 (25-S) である。

第2図 平削门粗さ見本
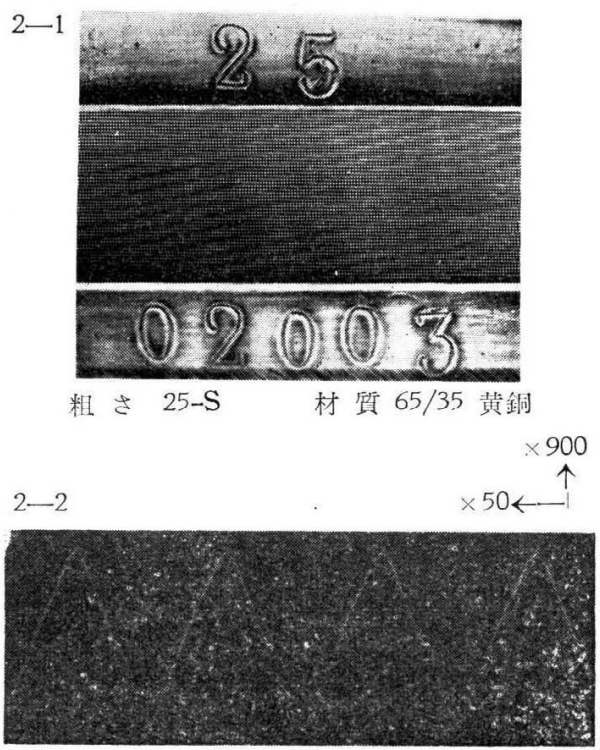

IV. 平面フライス削り

平面フライス削り面の切削方向（则ちテーブルの縦送
りの方向) の粗さは一般化次式で示される。

$$
\begin{aligned}
H \max & \div \frac{S^{2}}{8 r}\left\{1-\frac{S Z}{\pi r}\right\} \\
& \div \frac{S^{2}}{8 r}
\end{aligned}
$$

侣し $\operatorname{Hmax}$ : 粗さ $S$ : フライス 1 及当りの送り $r$ : フライスの半径 $Z$ : フライスの要数

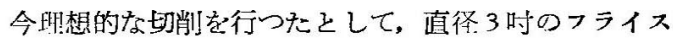

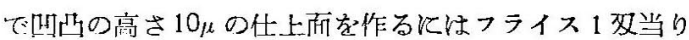
の送り $S$ 約 $1.7 \mathrm{~mm}$ になり実際にこんな租い送りで削 ることはないのでする。徒つて切削方向に粗さを測定し

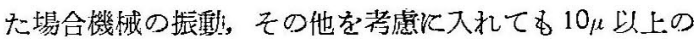
粗さは考えられない。但しフライスの切昧が要い場合は 諭外である。

次に切削方向に直角に粗ざを測定した場合には（一般 の加工法汶対してはかく行うのであるが）フライスの多 先の矿削状洗がそのま小曲線にあられれる。作し普通の 条件ならば $25 \mu$ 超えることは先ずないと考えられる。

JIS では平面フライス加工 3-S〜100-S となつてい るが, フライスの revolution mark はあくまたうねり と考息，深さも大したことはないので，粗さの測定方向

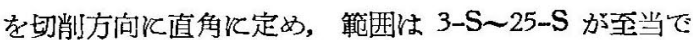
はない名と思われる。

第3図は一㱠厄切削方向に直角な方向の粗さはフライ スの研ぎ方によつてもつと粗くも，細かくるなるのであ 子。

第 3 図 平面フライフ仕上粗さ胃本

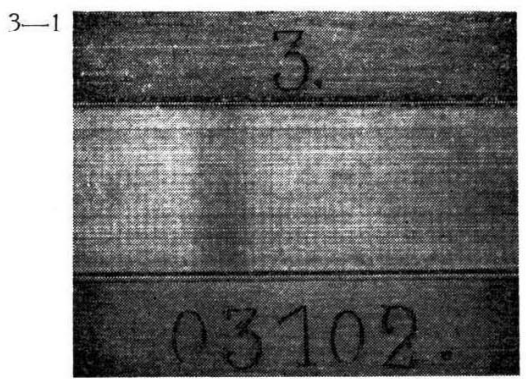

粗 さ 3-S 材 質 快削黄銅

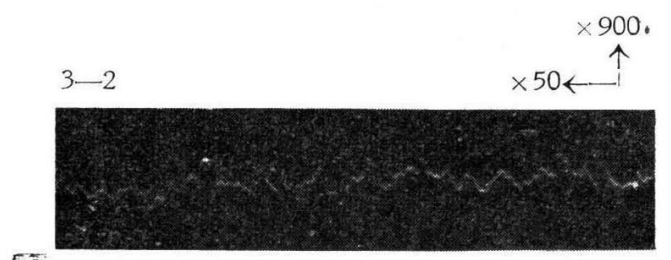

切削方向飞直角な方向の粗さ曲線

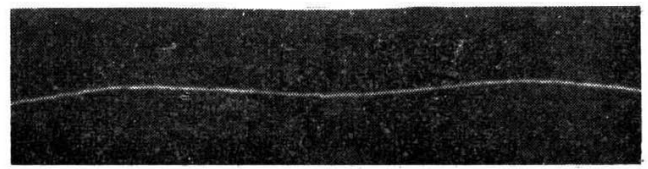

切削方向 の粗さ曲線 


\section{V. 正面フライス削り}

これイはあまり閒題はない。JISでは3-S〜100-Sの

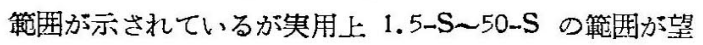
ましい。此の場合測定方向に上り俎さ曲線の非状が異つ て来るので注意る要する。

第4図は正面フラィス仕上見本の一例である。

苐4図正面フライス仕上粗さ見本

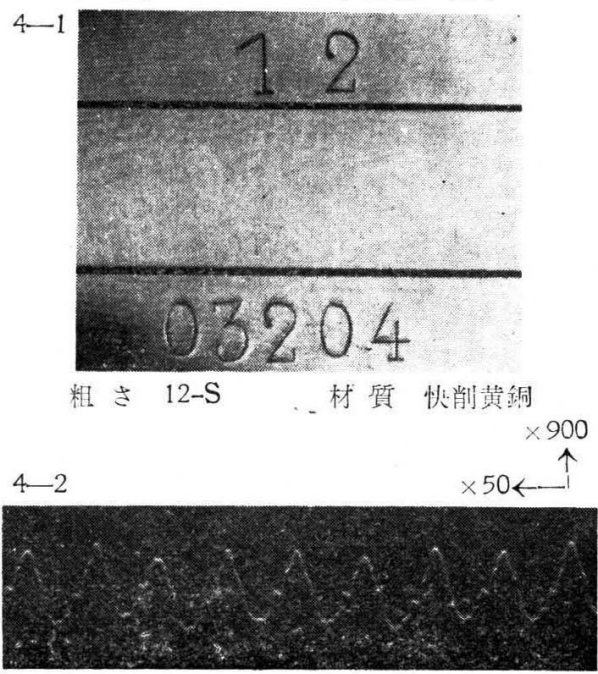

\section{VI. 研 削 仕 上}

JIS では 0.4-S から 50-S の範囲が示されている。正

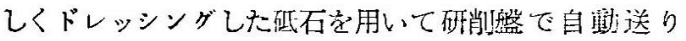
で加工した場合，いか炏粒度の粗い研石を用いても世凸 の高さが，8 8超えるすのはなかつた。從つて JISの 18-S〜50-S 以錆肌とか熔接部の仕上䎲 Hand Grinder を用いた時の粗ざですつ，正規の研削盤を用いる場合

第5図平面研刿粗さ見本

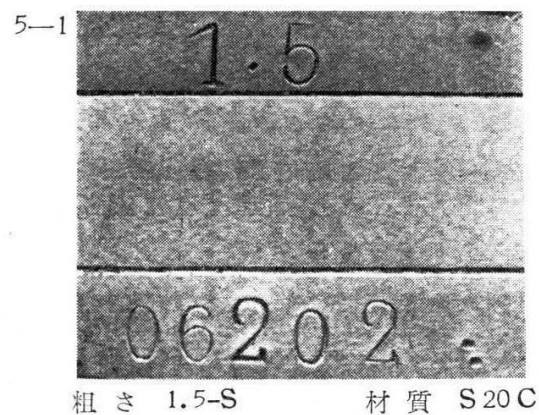

$\times 900$

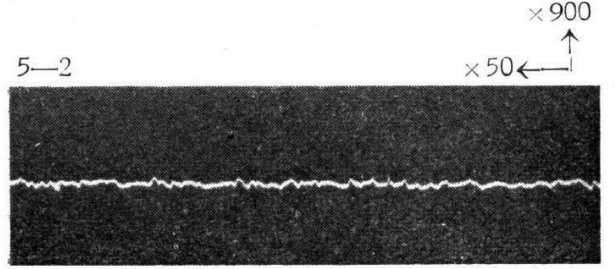

は 0.4-S〜12-S の加工範囲となる。

第 5 図は平面研削粗さ見本の例である。

VII. 丸 削

JIS では 0.4-S から 560-S をで殆んど粗さの全領域に 亘つた範囲が示されている。

しかしながら0.4-S の粗さは如何に旋盤および材料を 吟味し，切削条件を最息化してす，作ることはできなか つた。よく考えてみると当然なこてか子知れない。また

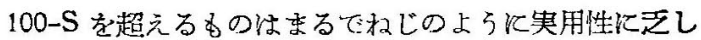
いと思かれるので桨来は 0.8-S〜100-S の符用にするの 加妥当加と考える。

第6 図 丸削り粗さ胃本
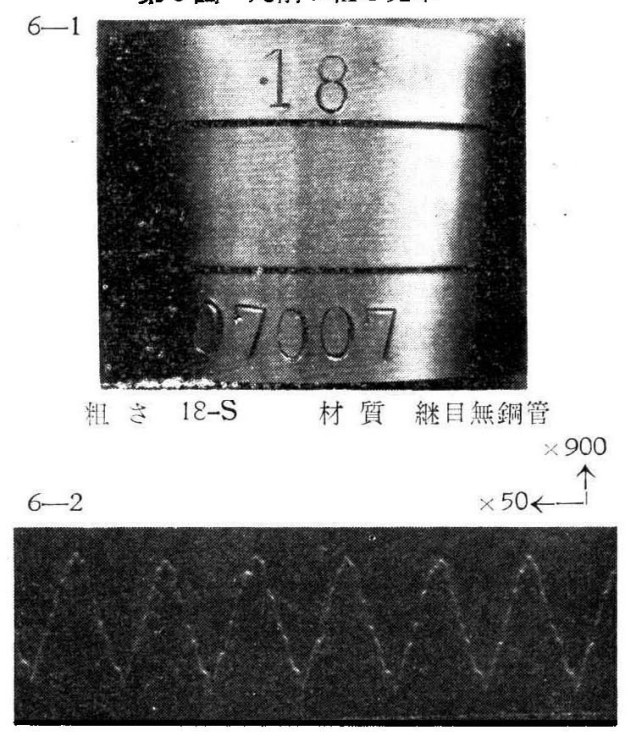

第 6 図は継日舆鋼管を切削速度 $270 \mathrm{~m} / \mathrm{minでウィディ}$ アの超媔チップを用いて切削したものでするが，此の材

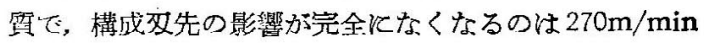
以上でむることを粗さ曲線の観察に依り知り得た。

\section{VIII. 中 倽 リ}

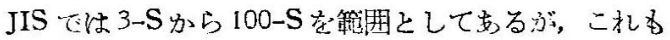

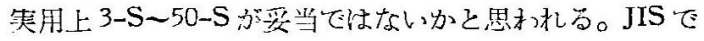
第7図中娜り倠さ見本

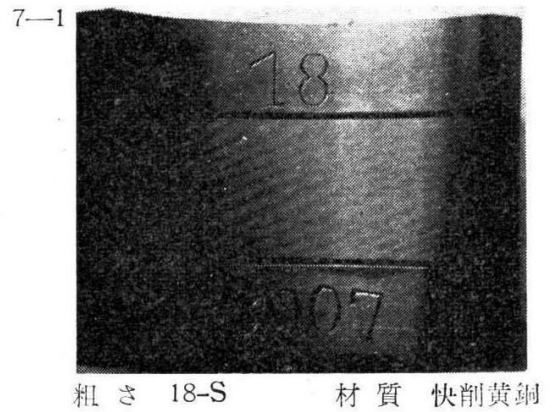




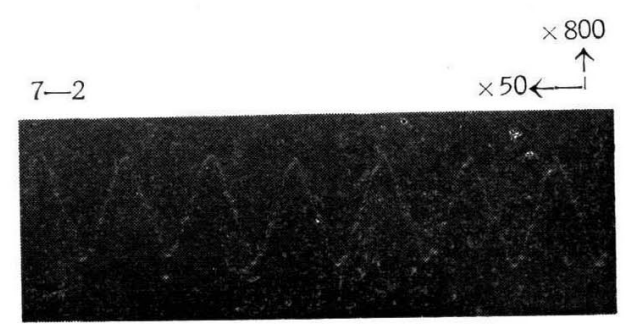

は精密中渮りの項があつて，0.8-Sから6-S なでの範团 が示されているが，これは妥当の上うに思われる。

第7四は中殻り粗さ見本の一例である。

\section{XI. ペーパー仕上; パフ仕上}

最近では研糜材会社の粒度に関する管理が向上したた め。例元ばある粒度のペーパーを用いて，材䁈と研摩圧 力を決めれい゙必ず，きまつた粗さが得られる。何遍やつ てみてわ，る粒度については必ず同じ粗さになるので 当然のことか子知れないが，变な気がした程で女る。

JIS ではペーパー仕上の筙囲は 0.4-S〜6-S, バフ仕 上は 0.2-S〜12-S 洂されているが，実験の結果これ

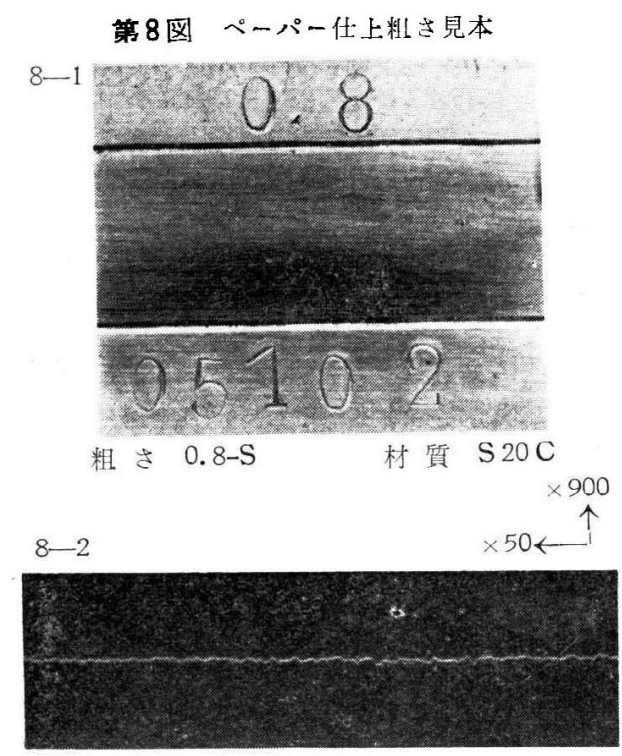

管 9 図バフ任上粗さ見本

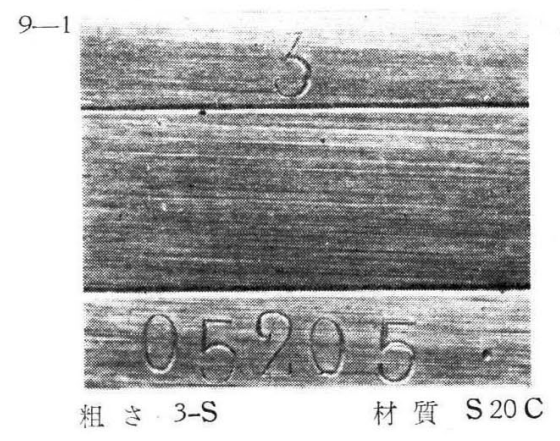

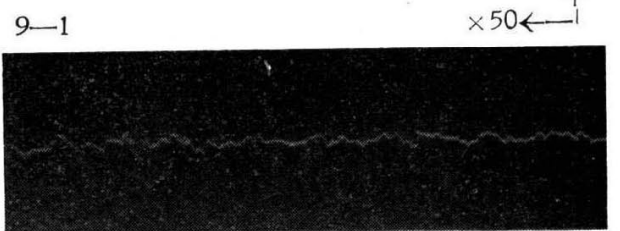

は妥当と思われる。第 8 図，第 9 図がその一例である。

\section{X.やすり仕上}

やすり仕上は最わ原始的な方泆であるが，仲々廃れそ らにない版法である。これはピッチ正しく配列されれた 沢山の切多が品物の表面を引搔いて行く版工洗である。 やすり仕上の粗さ师線は非常飞特幑が离り，一見してそ れと分る。即ち高い山，深い谷があるかと思うと，割合

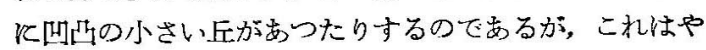
すりの切多面が平坦でなく，かい一つの切及の後に少し ずり位相のずれた切双が続いて行くからである。你つて やすり仕上面の粗さは眼で見て感じる程細くはない。 また面白いことにいかなる旒同のやすりで仕比でる， 3う-S 以上は粗くならないのである。ただしれやすりを 用いる場合は切削王力が愇つて来るのでこの限りでな w。

JIS の指定は 3-S〜50-S となつているが、3-S〜25-S の範囲が妥当ではないかと思わ水る。

第10樏はやすり仕上の一例である。

第10図やすり仕上粘さ㫕本

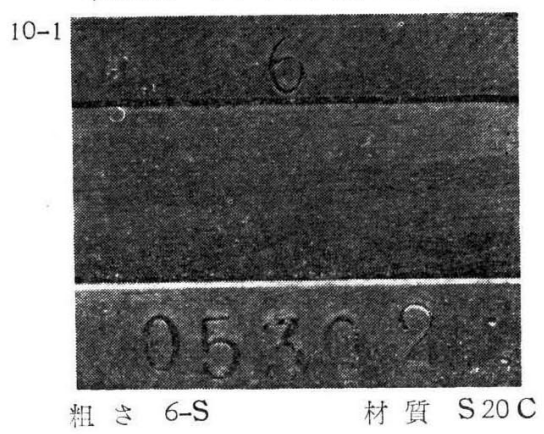

$10-2$
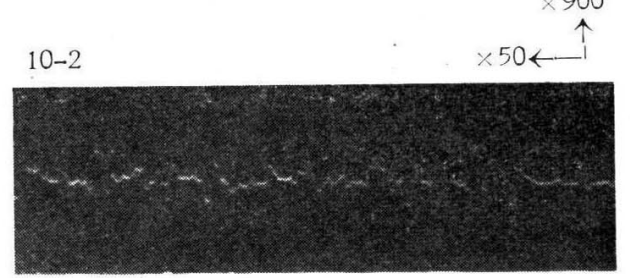

(1955.11.15 受理)

交献

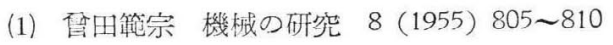

